\title{
Pliktkollisjoner som tolkningsresultat
}

Norsk rettsteori har lenge fulgt Torstein Eckhoff $i$ å hevde at enhver kollisjon mellom to plikter kun er tilsynelatende og vil fjernes gjennom en harmoniserende tolkning. Artikkelen kontrasterer denne etablerte modellen med en alternativ påstand om at pliktkollisjoner er mulige, om enn uheldige, forekomster i retten. Når disse alternative påstandene holdes opp mot de to fraksjonenes begrunnelse i Rt. 2010 s. 612 Sårstell, avdekkes en rekke utfordringer for Eckhoffs modell. Disse er dels at den etablerte modellen har vansker med å angi innholdet i rettskildenormene som skal avverge potensielle kollisjonstilfeller, dels at slike normer ikke garanterer optimale tolkningsutfall, dels at modellen hviler på et restriktivt syn på lovgivers kompetanse og dels at modellen underkommuniserer de vanskelige avgjørelsene som pliktsubjekter står overfor i møte med en tilsynelatende kollisjon. For å holde fast ved at pliktkollisjoner er umulige tolkningsresultater, fordres en mer detaljert redegjørelse enn norsk rettsteori så langt har tilbudt.

Nøkkelord: Pliktkollisjon, motstrid, rettskildelære, rettskildeprinsipper

\section{Innledning ${ }^{1}$}

Kommunale sykehjem er påbudt å yte medisinsk behandling, og behandling fordrer som hovedregel pasientens samtykke. ${ }^{2}$ Det kan imidlertid hende at en pasient motsetter seg behandling, slik at den eneste måten for sykehjemmet å oppfylle behandlingsplikten er gjennom bruk av tvang. Hvis man videre ser for seg at sykehjemmets ansatte mangler den nødvendige tvangshjemmelen, så er de nødt til å ta et valg. De kan enten velge å oppfylle behandlingsplikten og dermed bryte tvangsforbudet, eller de kan respektere tvangsforbudet og dermed la behandlingsplikten stå uoppfylt.

Dette var den rettslige situasjonen som mindretallet beskrev i Rt. 2010 s. 612 Sårstell (dissens 3-2). Mens flertallet konkluderte med at sykehjemmet hadde det nødvendige rettsgrunnlaget for bruk av tvang, holdt mindretallet fast ved at regelverket, slik det var utformet på avgjørelsestidspunktet, ikke inneholdt noen slik tvangshjemmel. Situasjonen som mindretallet dermed beskriver, kalles her en pliktkollisjon. ${ }^{3}$ Kollisjonstilfellet kjennetegnes ved at et rettssubjekt er underlagt to plikter - her en

\footnotetext{
${ }^{1}$ Takk til mine veiledere Christoffer Conrad Eriksen og Alf Petter Høgberg. Et tidlig utkast til artikkelen ble lagt frem og kommentert i et seminar som foruten mine veiledere inkluderte Svein Eng, Benedikte Høgberg og Anders Narvestad; takk for verdifulle innspill. Takk også til Åshild Marie Vige og Liv Artemis Lazaridis Nygaard for forskningsstøtte. Epost: j.v.wibye@jus.uio.no.

2 Jf. lov 19. november 1982 nr. 66 om helsetjenesten i kommunene § 2-1, lov 2. juli 1999 nr. 63 om pasient- og brukerrettigheter $\S 4-1$ (1).

${ }^{3}$ Den anvendte terminologien forutsetter at rettigheter og plikter står i et nødvendig gjensidighetsforhold, slik at en kollisjon mellom to plikter er ensbetydende med en kollisjon mellom rettighetene korrelert med
} 
behandlingsplikt og et forbud mot å bruke tvang - og hvor oppfyllelsen av den ene plikten vil lede til den andre pliktens overtredelse. Pliktbrudd er dermed uunngåelig.

Emnet for denne artikkelen er følgende spørsmål: Er pliktkollisjon et mulig doms- og tolkningsresultat? Kan to plikter begge være gjeldende rett dersom oppfyllelsen av den ene plikten innebærer brudd på den andre? Mitt formål er å kartlegge og evaluere hvordan dette spørsmålet har blitt besvart i norsk rettskildelære og rettsteori.

Den rådende oppfatningen er at pliktkollisjoner er utelukket. ${ }^{4}$ Dette standpunktet begrunnes med at retten ikke kan kreve det umulige, i den forstand at det ikke er adgang til å sette rettssubjekter i en situasjon hvor pliktbrudd er uunngåelig. Oppfatningen får direkte tolkningskonsekvenser. Om man slutter seg til at pliktkollisjoner er umulige tolkningsresultater, så synes man i en sak som Sårstell også å være nødt til å velge flertallets resultat (pliktkollisjon unngås fordi sykehjemmet hadde hjemmel til å bruke tvang) over mindretallets resultat (sykehjemmet hadde ingen måte å unngå pliktbrudd). Påstanden om at pliktkollisjoner er umulige, kan med dette også uttrykkes som et tolkningsprinsipp om at pliktkollisjoner må avverges gjennom harmonisering av rettskilder.

Artikkelen går frem som følger: I punkt 2 vil jeg redegjøre for ulike tilfeller av konflikt mellom rettigheter, og forklare sondringen mellom pliktkollisjon og logisk uforenlighet. Disse to gruppene har tradisjonelt blitt slått sammen under fanen «logisk motstrid». ${ }^{5}$ De er imidlertid vesensforskjellige. Den logiske slutningen som gjør at vi kan utelukke at to uforenlige utsagn om retten er sanne, kan ikke brukes til å utelukke kollisjonstilfellet. I punkt 3 kontrasterer jeg så to ulike syn på pliktkollisjoner. Torstein Eckhoff hevdet at tolkning avslører enhver pliktkollisjon som tilsynelatende. I den grad man i rettsvitenskapen taler om motstrid, så er dette, ifølge Eckhoff, kun mellom «regler» forstått som mellomstasjoner for tankene i en juridisk avgjørelsesprosess. Kollisjonstilfeller rammer dermed aldri «de virkelig gjeldende regler, men reglene slik de i første omgang fortoner seg for oss». ${ }^{6}$ Eckhoffs syn kontrasteres deretter med modellen foreslått av Hans Kelsen, hvor pliktkollisjoner aksepteres som mulige, om enn uheldige, fenomener i retten. Fremfor å kvittere ut pliktkollisjoner på

pliktene. Begrepsapparatet følger her analysen av rettsposisjoner utviklet i Wesley N. Hohfeld, Fundamental Legal Conceptions as Applied in Judicial Reasoning, Clark, New Jersey: Lawbook Exchange 1964 s. 36, 39, 50 og 60. Analysens begrepsapparat og innhold er nærmere forklart i Johan Wibye, "Hohfelds rettigheter», Tidsskrift for Rettsvitenskap (2018), s. 498-505.

${ }^{4}$ Se f.eks. Carl Jacob Arnholm, Privatrett 1: Almindelig privatrett, Oslo 1964 s. 128; Torstein Eckhoff, «Når foreligger kollisjon mellom rettsregler?», i Nordisk gjenklang: Festskrift til Carl Jacob Arnholm, Knut Selmer (red.), Oslo 1969 s. 81, Torstein Eckhoff og Nils Kristian Sundby, Rettssystemer, 2. utg. Oslo 1991 s. 72, Torstein Eckhoff og Jan E. Helgesen, Rettskildelære, 5. utg., Oslo 2001 s. 343. Sml. Svein Eng, Rettsfilosofi, Oslo 2007 s. 73.

${ }^{5}$ Eckhoff og Helgesen (2001) s. 343.

${ }^{6}$ Eckhoff og Helgesen (2001) s. 343. 
teoretisk grunnlag, holdt Kelsen det for rettsvitenskapens oppgave å synliggjøre dem, slik at de kan fjernes gjennom en rettsendring.

Punkt 4 evaluerer de to foreslåtte modellene. Eckhoffs retroaktive identifikasjon av «de virkelig gjeldende reglene» er en teoretisk elegant løsning, men den etterlater også en rekke ubesvarte spørsmål. Det er vanskelig å formulere innholdet i normene som angivelig skal avverge kollisjonstilfellene, og slike normer er ingen garanti for optimale tolkningsutfall. Fra den normative påstanden om at pliktkollisjoner er noe som bør unngås, følger det heller ikke at det ligger utenfor lovgivers kompetanse å skape slike situasjoner. Eckhoffs Iøsning underkommuniserer til slutt de vanskelige valgene som rettssubjekter må foreta i forkant av en eventuell rettsavklaring. Underveis i denne drøftelsen vil jeg bruke de to fraksjonenes begrunnelse i Sårstell til å illustrere virkningene av å fornekte pliktkollisjoner som fenomen, med særlig vekt på hvordan Eckhoffs løsning synes å forplikte oss til å velge flertallets resultat over mindretallets. Om man etter dette vil holde frem med påstanden om at pliktkollisjoner er umulige, så er man nødt til å gi en mer fyldig begrunnelse enn norsk rettsteori så langt har tilbudt. Til et slikt prosjekt hører å forklare hvorfor det skal være rettsvitenskapens oppgave å glatte over kollisjonstilfeller fremfor å synliggjøre dem. Punkt 5 oppsummerer.

\section{Konflikttilfellene}

\subsection{Hverken pliktkollisjon eller logisk uforenlighet}

Det kan oppstå spenninger når begrensede ressurser skal fordeles, eller når det må foretas en avveining mellom motstridende interesser. En ny sykkelvei vil kunne bety mindre rom for biltrafikk, og en rettighetsfestet frihet til å følge et religiøst bud om å omskjære guttebarn vil være i spenning med barnets rett til fysisk integritet. Slike og lignende tilfeller kan beskrives som interessekonflikter, eller som tilfeller av konkurranse eller spenning mellom rettigheter. De bør imidlertid neppe kalles «kollisjoner». Det er retorisk kraft i kollisjonsbegrepet, men ved å ty til slik terminologi risikerer man å fremstille konflikter som mer tilspissede enn nødvendig. ${ }^{7}$

Høyesterett synes å være denne faren bevisst. I Rt. 2005 s. 833 Uskyldspresumsjon anførte påtalemyndigheten at det forelå en «rettighetskollisjon» mellom, på den ene hånd, siktedes rett til å føre bevis om skyldspørsmålet og, på den annen, det objektive straffbarhetsvilkåret i daværende straffelov 1902 § 195 (3), som blant annet var motivert av myndighetenes plikt til å beskytte barn mot seksuell utnytting etter artikkel 34 i Barnekonvensjonen. ${ }^{8}$ Retten tok avstand fra

\footnotetext{
${ }^{7}$ Se Russell Sandberg, "The Future of Religious Freedom», i When Human Rights Clash at the European Court of Human Rights, Stijn Smet og Eva Brems (red.) Oxford 2017 s. 141 og 146.

${ }^{8}$ Almindelig borgerlig straffelov 2. mai $1902 \mathrm{nr}$. 10 og FNs konvensjon om barnets rettigheter av 20 november 1989.
} 
påtalemyndighetens begrepsbruk, og uttalte at «Barnekonvensjonens krav til beskyttelse av barn mot seksuelle overgrep ville ha vært oppfylt selv om det ikke hadde vært gjort unntak fra de alminnelige regler om kravet til skyld i § 195 og § 196». ${ }^{9}$ Rettens poeng er at en oppfyllelse av plikten til å respektere siktedes uskyldspresumsjon etter Den europeiske menneskerettighetskonvensjon (EMK) artikkel 6 (2) ikke automatisk vil lede til brudd på plikten til å beskytte barn. Det foreligger kanskje en spenning mellom siktedes og barns rettigheter, men ingen kollisjon.

\subsection{Pliktkollisjon}

Det foreligger en pliktkollisjon når et rettssubjekt er bundet av to plikter og den enes oppfyllelse vil lede til den andres overtredelse. I litteraturen har kollisjonstilfeller blitt identifisert ved hjelp av en såkalt «impossibility-of-joint-compliance» test; det avgjørende kjennetegnet ved kollisjonstilfellet er at det er umulig for pliktsubjektet å unngå et pliktbrudd..$^{10}$

Kollisjonsbegrepet brukes med dette på en måte som delvis overlapper med begrepet «motstrid» $\mathrm{i}$ rettskildelæren. ${ }^{11}$ Merk imidlertid at emnet kun er kollisjoner på regelnivå, og ikke på rettskildenivå. ${ }^{12}$ Kollisjonstilfellet forutsetter videre at de to kolliderende pliktene gjelder overfor samme pliktsubjekt, og at de er relatert til samme handling. ${ }^{13}$ Hvorvidt kollisjonsbegrepet kan anvendes på motstrid

\footnotetext{
${ }^{9}$ Rt. 2005 s. 833 (avsnitt 78).

${ }^{10}$ Hamner Hill, «A Functional Taxonomy of Normative Conflict», Law and Philosophy (1987), s. 227. Sml. Manfred Moritz, Über Hohfelds System der juridischen Grundbegriffe, Lund 1960 s. 47-48.

${ }^{11}$ Begrepet «motstrid» har blitt brukt til å betegne enhver uforenlighet mellom regler, også der normene er kun delvis inkompatible eller motvirker hverandre, se Eckhoff (2001) s. 343. Sml. Ross, Om ret og retfærdighed, København 1953, s. 150. Denne artikkelen forholder seg kun til kollisjon mellom rettsnormer, og ikke mellom moralske normer. For en drøftelse av samspillet mellom disse to emnene, se Henning Herrestad, Formal Theories of Rights, Oslo 1996 s. 101 og Matthew Kramer, Nigel Simmonds, og Hillel Steiner, A Debate Over Rights, Oxford 1998 s. 135-138.
}

${ }^{12}$ Skillet problematiseres i Jan Helgesen, «Er det fruktbart å operere med begrepet 'motstrid mellom rettsregler' eller løses problemene best via harmonisering av rettskildefaktorer alene?», Jussens Venner (1979), s. 1-13.

${ }^{13} \mathrm{Sml}$. Kramer mfl. (1998) s. 18. Dermed avgrenses emnet mot tidligere diskusjoner fra blant annet Hagerup og Arnholm. Hagerups valgte eksempel på kollisjon er et vitne som innkalles til to forskjellige domstoler på forskjellig sted til samme tid, se Francis Hagerup, Strafferettens almindelige del, Kristiania 1911 s. 255. Her er det klart at oppfyllelsen av den ene vitneplikten vil utelukke oppfyllelsen av det andre, men denne dynamikken skyldes ikke innholdet i de to rettspliktene - pliktene er like. Dynamikken skyldes en ekstern faktor - tidsnød. Jeg vil heller ikke ta stilling til om artikkelens drøftelse er overførbar til handlinger i betingelseskjeder, som for eksempel der det gjøres innbrudd i en fjellhytte for å få en såret venn inn i varmen. I en slik situasjon er pliktbruddet riktignok et nødvendig vilkår for å oppfylle en redningsplikt, men innbruddet og redningen er fremdeles faktisk og kronologisk distinkte handlinger. For et lignende eksempel, se Arnholm (1964) s. 61. Det er imidlertid noe overlapp i drøftelsens konklusjoner: Hvorvidt en redningsplikt kansellerer plikten til å ikke begå innbrudd, må avgjøres ved tolkning og ikke ved logisk slutning. En som har plikt $X$, hvis oppfyllelse er blokkert av plikt $Y$, er ikke uten videre fritatt plikt $Y$. Tilsvarende, en som har rettighet $X$, som 
mellom regler ferdig tolket og utfylt, eller er forbeholdt motstrid mellom «regler» som navnet på en mellomstasjon for tankene i en tolkningsprosess, hører som nevnt til artikkelens sentrale problemstilling.

Pliktkollisjon har allerede blitt eksemplifisert gjennom mindretallets rettsbeskrivelse i Sårstell. Å behandle pasienten As sår uten samtykke ville, i fravær av en tvangshjemmel, være i strid med et forbud mot å bruke tvang. I den andre retning, å respektere tvangsforbudet ved å ikke stelle sårene, eller å utskrive pasienten, ville være i strid med behandlingsplikten. ${ }^{14}$ Kollisjonen i Sårstell kan sammenlignes med et ytterligere eksempel:

Eieren av et kraftverk får to pålegg. Det ene er en rekvisisjon etter energiloven § 6-2 (1) om å igangsette kraftproduksjon umiddelbart, det andre et pålegg om å ikke starte kraftproduksjon i mangel av konsesjon etter energiloven $\S 3-1(1) .{ }^{15}$ Eieren kan ikke oppfylle påbudet uten å bryte igangsettelsesforbudet, og motsatt.

Dette kraftverk-eksempelet er et mer renskåret tilfelle av kollisjon, i den forstand at kollisjonen skyldes at samme handling - å produsere kraft - er både påbudt og forbudt. Eksempelet er imidlertid også mer primitivt. Det er mye mer sannsynlig at kollisjon oppstår som følge av et uventet samspill mellom to regler som i utgangspunktet ikke er forbundet, slik det var i Sårstell, enn at tilfellet oppstår på grunn av samtidige påbud og forbud. ${ }^{16}$ Lignende tilfeller som i kraftverk-eksempelet har blitt drøftet av Kelsen og Ross, og disse vil bli omtalt i punkt 3.3. ${ }^{17}$

\subsection{Logisk uforenlighet}

Den andre kategorien av rettighetskonflikt, logisk uforenlighet, kan illustreres ved å sammenligne følgende to utsagn:

Utsagn 1: «Det er plikt til å bruke belte».

Utsagn 2: «Det er ikke plikt til å bruke belte».

ikke kan nytes uten rettighet $\mathrm{Y}$, kan ikke dermed antas å ha rettighet $\mathrm{Y}$, se John L Mackie, "Can There be a Right-Based Moral Theory?», Midwest Studies in Philosophy (1978), s. 351.

${ }^{14}$ Rt. 2010 s. 612 Sårstell (avsnitt 35). For en drøftelse av et mulig skille mellom «bilaterale» og «unilaterale» rettighetskonflikter, se Hans Kelsen, Essays in Legal and Moral Philosophy, Dordrecht 1973 s. 269 flg. Merk at denne sondringen er en annen enn ved Eckhoff og Ross' drøftelse av «partiell» og «total» konflikt ved sammensatte rettigheter, se Ross (1953) s. 150 flg og Eckhoff og Helgesen (2001) s. 346.

${ }^{15}$ Jf. lov 29. juni $1990 \mathrm{nr} .50 \mathrm{om}$ produksjon, omforming, overføring, omsetning, fordeling og bruk av energi m.m.

${ }^{16}$ H.L.A. Hart, Essays in Jurisprudence and Philosophy, Oxford 1983 s. 325.

${ }^{17}$ Alf Ross, Directives and Norms, London 1968 s. 172-174 og Kelsen (1973) s. 270. 
Disse to utsagnene handler om en (og samme) rettsnorm. Ifølge utsagn 1 finnes det en plikt til å bruke belte, og ifølge utsagn 2 finnes den ikke. Det følger at utsagnene er hverandres negasjon. Hvis jeg påpeker at du har plikt til å bruke belte, så ligger det i denne påpekningen at du ikke har adgang til å la være å bruke belte. Det er den gjensidige negasjonen som gjør utsagnene logisk uforenlige, i den forstand at det vil være selvmotsigende å hevde at både plikten til å bruke belte og friheten til å la være er gjeldende rett. Det er helt umulig for plikten til å bruke belte å både eksistere og ikke eksistere, akkurat som det er umulig å være både over og under 1.80 høy, eller å være både gift og ugift. ${ }^{18}$

Påstanden her, og påstanden som den videre drøftelsen vil gjenfinne hos blant annet Hohfeld, Kelsen, Ross, Eckhoff, Opsahl og Hart, er at logisk uforenlighet er det eneste tolkningsresultatet som en rettsanvender kan utelukke gjennom ren formallogisk slutning. ${ }^{19}$ Andre eksempler på logisk uforenlighet er relativt enkle å formulere. Det kan ikke, slik Ross skrev, foreligge både et påbud og fravær av påbud om å lukke et vindu. ${ }^{20}$ En og samme person kan ikke både ha en adgang til å krysse et jorde og en plikt til å la være. Det ville være selvmotsigende å hevde både at en kommune har kompetanse til å innvilge dispensasjon fra byggeforbudet i strandsonen og at kommunen mangler slik kompetanse. Og det vil være inkoherent å hevde at borgere både er vernet mot og utsatte for effekten av en retroaktiv lov.

Fordi det kun er logisk uforenlige tolkningsresultater som kan utelukkes gjennom formallogisk slutning, er det avgjørende å kunne skille dem fra pliktkollisjoner. ${ }^{21}$ Den forestående drøftelsen vil vise hvordan sammenblandingen av de to tilfellene har ledet debatten om pliktkollisjoner på avveie: Etter å ha brukt logisk slutning til å slå fast at to logisk uforenlige rettsnormer ikke begge kan være gjeldende rett, brukes samme type argumentasjon til å utelukke pliktkollisjoner. De to tilfellene er imidlertid ikke like. Ifølge Kelsen er de ikke engang sammenlignbare. ${ }^{22}$

Forskjellen mellom logisk uforenlighet og pliktkollisjon er, i én setning, forskjellen mellom tilfellet hvor en norm både finnes og ikke finnes og tilfellet hvor to plikter ikke begge kan oppfylles. Dette kan illustreres ved å sammenligne utsagn 1 og 2 med følgende to utsagn:

\footnotetext{
${ }^{18}$ Ross (1968) s. 170 og Kramer mfl. (1998) s. 8.

${ }^{19}$ Hohfeld (1964) s. 39, Torkel Opsahl, Delegasjon av Stortingets myndighet, Oslo 1965 s. 296, Ross (1968) s. 174, Kelsen (1973) s. 235, Hart (1983) s. 325-326 og Eckhoff og Helgesen (2001) s. 334.

${ }^{20}$ Ross (1968) s. 170. Sml. Moritz (1960) s. 47.

${ }^{21}$ En videre grunn til å skille mellom pliktkollisjon og logisk uforenlighet, er at pliktkollisjon ikke er en aktuell problemstilling for dynamiske relasjoner som kompetanser og immunitet. Det er kun logisk uforenlighet som er en meningsfull problemstilling ved tolkning av disse, se Eckhoff (1969) s. 97-98.

${ }^{22}$ Kelsen (1973) s. 271.
} 
Utsagn 3: «Det er påbudt å bruke belte.»

Utsagn 4: «Det er forbudt å bruke belte.»

Forholdet mellom disse to utsagnene er et helt annet enn mellom utsagn 1 og 2 . For det første er de ikke hverandres negasjon. Utsagn 3 gir uttrykk for et påbud, altså en plikt til å handle. Det motsatte av påbudet er en frihet til å la være å bruke belte (og ikke et forbud mot å bruke belte). Utsagn 4 gir uttrykk for et forbud, altså en plikt til å ikke handle. Det motsatte av forbudet er en frihet til å bruke belte (og ikke et påbud om å bruke belte). ${ }^{23}$

For det andre, og siden de ikke er hverandres negasjon, tjener ikke utsagn 3 som benektelsen av utsagn 4, eller motsatt. Hvis en handling er påbudt, kan man altså ikke bruke ren formallogikk til å slutte seg frem til et fravær av forbud. Sagt på en annen måte, pliktkollisjon er mulig fra et rent formallogisk perspektiv. ${ }^{24}$

For det tredje utgjør sammenstillingen av utsagn 3 og 4 en pliktkollisjon. Om både påbudet og forbudet mot å bruke belte var gjeldende rett, ville det ikke finnes noen måte for pliktsubjektet å unngå et pliktbrudd; en oppfyllelse av påbudet ville bryte med forbudet, og motsatt. Likevel er ikke de to utsagnene hverandres benektelse. Dette betyr at hvis man vil benekte at pliktkollisjoner er mulige tolkningsresultater, så må man begrunne sitt standpunkt på annen måte enn ved hjelp av ren formallogikk. Det er for å se hvilke alternative grunnlag som finnes for å fornekte pliktkollisjoner at jeg i neste punkt kartlegger håndteringen av kollisjonstilfeller $\mathrm{i}$ juridisk teori.

\section{Omtale av pliktkollisjon}

\subsection{Utgangspunkter}

Det er noen grunnleggende egenskaper ved pliktkollisjoner som bør slås fast ved starten av en diskusjon av om de er mulige tolkningsresultater. Ett av disse er at fornektelsen av pliktkollisjoner har et sterkt grunnlag i intuisjon. I Sårstell, for eksempel, virker det svært urimelig at sykehjemmet skal ha en behandlingsplikt uten å ha tvangshjemmelen som trengs for å oppfylle behandlingsplikten. Det virker tilsvarende urimelig (og forvirrende) å gi eieren av et kraftverk både et påbud om og et forbud

\footnotetext{
${ }^{23}$ Moritz (1960) s. 46-47. En påstand om praktisk kollisjon kan uttrykkes som konjunksjonen ( $\wedge$ ) av en plikt (P) til å gjøre en handling $(H)$ og til å avstå fra å handle $(-H)$, slik at $\mathrm{P}(\mathrm{H}) \wedge \mathrm{P}(-\mathrm{H})$. Logisk uforenlighet kan uttrykkes som negasjonen av konjunksjonen mellom en plikt til å handle og pliktens fravær, slik at - $(P(H) \wedge-P(H))$.

${ }^{24}$ Jf. Moritz (1960) s. 47. Moritz' resonnement går, i korte trekk, slik: Hvis vi tar utsagnet i) «En plikt til å gjøre H impliserer ikke en frihet til å gjøre $H »$ og husker at ii) frihet er det samme som et fravær av plikt og nærmere bestemt at iii) frihet til å gjøre $\mathrm{H}$ er det samme som [et fravær av plikt til å ikke gjøre $\mathrm{H}$ ] kan iii) erstattes for «frihet» $\mathrm{i}$ (i), hvilket gir påstanden iv) plikt til å gjøre $\mathrm{H}$ impliserer ikke et fravær av forbud [et fravær av en plikt til å ikke gjøre $\mathrm{H}]$.
} 
mot å produsere kraft. Stilt overfor en påstand om at samme handling er både påbudt og forbudt, er den instinktive reaksjonen hos en jurist at slik kan det ikke være. Det hører til artikkelens formål å forklare og nyansere denne reaksjonen.

Pliktkollisjoner, hvis de finnes, er også vanskelige å få øye på. Grunnlaget for rettskildeprinsipper er (som alle andre normer i retten) et sett med verdipremisser, og ett av disse er at man ved tolkning bør se hen til resultatets godhet. ${ }^{25}$ Hver gang to rettsnormer ser ut til å kollidere, vil en rimelig løsning være å sette en eller begge normer til side gjennom en harmoniserende tolkning. Fra empirisk observasjon av at regler normalt samordnes gjennom tolkning, kan det være fristende å slutte at avvæpning av kollisjonstilfeller er en analytisk nødvendighet.

Mot påstanden om at alle kollisjoner vil avverges gjennom tolkning, taler det faktum at rettsanvendelse er en normstyrt prosess. Det finnes normer som angir hva som er god juridisk metode og, motsetningsvis, som angir hva som ikke er god metode. Så mens rettsanvenderen kan søke å unngå kollisjonstilfellet ved å presse rettskildene mot en harmoniserende tolkning, vil det også komme et punkt hvor tolkningen kan kritiseres for å ikke gjenspeile gjeldende rettskildenormer. Slik jeg vil argumentere for i punkt 4, ble disse grensene gjort tydelige i Sårstell.

Videre, selv om en pliktkollisjon er et urimelig resultat, er den ikke praktisk umulig. Dette kan illustreres med et tankeeksperiment. Hva ville skjedd hvis flertallet og mindretallet i Sårstell ble snudd, slik at tre dommere konkluderte at sykehjemmet manglet tvangshjemmel? For sykehjemmet ville dette resultatet betydd at deres bruk av tvang overfor pasient $A$ var et pliktbrudd. Virkningen ville være å sette kommunen i en potensiell økonomisk ansvarssituasjon og kanskje også å synliggjøre et mulig behov for rettsendring. Men det er ingenting ved rettens tolkningsresultat som ville være inkoherent. Etter å ha konstatert en pliktkollisjon og et pliktbrudd, ville hendelsesforløpet utspille seg på normal måte gjennom rettens erstatnings-, sanksjons-, lempnings- og lovendringsmekanismer. Rettens mekanismer kan med andre ord håndtere pliktbrudd også der de er uunngåelige, hvilket harmonerer dårlig med påstanden om at pliktkollisjon er et umulig tolkningsresultat.

\subsection{Eckhoffs syn på pliktkollisjon}

Det er slått fast i Eckhoffs Rettskildelære at man «aldri kan slå seg til ro med at det foreligger motstrid» mellom regler. ${ }^{26}$ Med denne påstanden følger to eksempler på regler som «motsier hverandre logisk»: (1) Motstrid mellom regler som pålegger plikter «hvis den ene plikt ikke kan

\footnotetext{
${ }^{25}$ Magnus Aarbakke, «Harmonisering av rettskilder», Tidskrift for Rettsvitenskap (1966), s. 510 og Benedikte M. Høgberg og Alf Petter Høgberg, "Grunnloven som rettskildefaktor», i Juridisk metode og tenkemåte, Alf Petter Høgberg og Jørn Øyrehagen Sunde (red.), Oslo 2019 s. 252.

${ }^{26}$ Eckhoff og Helgesen (2001) s. 343.
} 
oppfylles uten at den andre brytes», og (2) motstrid mellom «regler som pålegger plikter og regler som fritar for plikter $»{ }^{27}$ Disse eksemplene er gjenkjennelige som tilfeller av henholdsvis pliktkollisjon og logisk uforenlighet. De er også vesensforskjellige. Ved å slå dem sammen, under fanen av regler som «motsier hverandre logisk», skapte Eckhoff en betydelig fare for slutningsfeil: Mens det er en nødvendig sannhet at to logisk uforenlige utsagn om retten ikke kan beskrive gjeldende rett, kan ikke formallogisk slutning på samme måte brukes til å utelukke pliktkollisjoner.

I de snart 50 årene siden dens utgivelse, har Rettskildelære vært toneangivende for norsk juridisk metode. Dette gir seg blant annet til kjenne ved at pliktkollisjoner fremdeles blir omtalt som tilfeller av «logisk motstrid». ${ }^{28}$ Eckhoffs klassifisering av pliktkollisjoner som umulige kan imidlertid bare forsvares om man skiller mellom utsagn om oppfyllelseshandlinger og utsagn om underliggende rettsnormer. Eckhoff hadde rett i at jeg ikke kan hevde å ha oppfy/t et samtidig påbud og forbud; et slikt hendelsesforløp er umulig. Fra dette følger det likevel ikke at jeg er avskåret fra å hevde at påbudet og forbudet finnes. Det kan imidlertid neppe forventes at jurister som er utdannet i Eckhoffs tradisjon, leser hans påstander med et forbehold om at umuligheten i pliktkollisjon knytter seg til oppfyllelseshandlingen. Når en jurist blir fortalt at pliktkollisjon er et tilfelle av «logisk motstrid», er det mest sannsynlig at hun forstår dette som en påstand om forholdet mellom normer. For en som følger Eckhoff i å betrakte pliktkollisjon som et tilfelle av at to regler «motsier hverandre logisk», er det derfor kort vei til å hevde at det var umulig å konkludere som mindretallet gjorde i Sårstell. ${ }^{29}$

En videre følge av Eckhoffs tradisjon er at det blir nødvendig å tolke senere utsagn om rettighetskonflikt for å finne ut om de gjelder pliktkollisjon, logisk uforenlighet eller begge deler. Et sentralt eksempel er den nylig utgitte antologien Juridisk metode og tenkemåte, som har et eget kapittel viet til motstridsspørsmålet. Når det der fremgår at det ikke kan finnes flere «rettsregler som regulerer det samme spørsmålet med motstridende rettsvirkninger», er det viktig å være klar på at dette kun er en påstand om logisk uforenlighet, og ikke pliktkollisjon. ${ }^{30}$ Setningen peker på at det finnes rettsanvendelsessituasjoner hvor man er $n \emptyset d t$ til å velge mellom to gjensidig utelukkende tolkningsresultater. Hvis for eksempel spørsmålet er «Har kommunen kompetanse til å innvilge byggetillatelse?», så er man nødt til å svare enten «ja» eller «nei», og hvert svar utelukker det andre. I boken illustreres denne dynamikken med Rt. 2000 s. 1811 Finanger I (dissens 10-5), hvor retten fant at en nasjonal regel om bortfall av erstatning var direktivstridig. Ettersom direktivene enda ikke

\footnotetext{
${ }^{27}$ Eckhoff og Helgesen (2001) s. 343.

${ }^{28}$ Se senest Benedikte M. Høgberg, «Harmonisering og motstrid», i Juridisk metode og tenkemåte, Alf Petter Høgberg og Jørn Øyrehagen Sunde (red.), Oslo 2019 s. 481.

${ }^{29}$ Wibye (2018) s. 525-527.

${ }^{30} \mathrm{H} \varnothing$ gberg (2019) s. 478 (min kursivering).
} 
var gjennomført i norsk rett, ble ikke regelen rammet av forrangsbestemmelsen i EØS-loven § 2. ${ }^{31}$ Retten fant heller ikke at de to reglene kunne samordnes ved hjelp av presumsjonsprinsippet. EØSregelen, som ivaretok partens erstatningskrav, og den nasjonale regelen, som fjernet det, var dermed gjensidig utelukkende. Gitt valget mellom to uforenlige resultater, lot flertallet den nasjonale bestemmelsen gå foran. ${ }^{32}$ Finanger I er med dette et godt eksempel på logisk uforenlighet, men saken taler overhodet ikke til spørsmålet om pliktkollisjon.

Gitt sammenblandingen av konflikttilfeller i Rettskildelære, er det noe overraskende at Eckhoff forsvarte et knivskarpt skille mellom pliktkollisjon og logisk uforenlighet $\mathrm{i}$ hans andre arbeider. I artikkelen Når foreligger kollisjon mellom rettsregler tok han til orde for, først, at «to pliktregler er uforenlige hvis, og bare hvis, det er umulig å oppfylle den ene uten å bryte den andre» og, videre, at eksistensen av et påbud om å handle er uforenlig med et fritak fra handleplikt. Disse to tilfellene beskrev han som vesensforskjellige. ${ }^{33}$ Det er de også. Det første er en pliktkollisjon, og det andre er en logisk uforenlighet. Eckhoffs tilslutning til samme sondring som ble forsvart i punkt 2, ville vært klarere for ettertidens jurister om Eckhoff unnlot å bruke termer som «logisk umulighet» eller «logisk uforenlighet» til å beskrive tilfeller av pliktkollisjon.

Det neste spørsmålet er hvordan Eckhoff betraktet de to tilfellene. For den logiske uforenligheten var svaret enkelt: Eckhoff anså det som umulig for to logisk uforenlige utsagn å begge gi uttrykk for gjeldende rett, ettersom «en og samme handling kan ikke både være forbudt og tillatt». ${ }^{34}$ Det samme standpunktet er bakt direkte inn i det Hohfeldianske begrepsapparatet som Eckhoff benyttet, i form av Hohfelds tese om motsatser. ${ }^{35}$ Hohfeld anerkjente kun én umulig sammenstilling av normer: Den samtidige eksistensen av en rettsposisjon og dens logiske motsats. For eksempel, i påstanden «Domstolene har en begrunnelsesplikt ved ankenektelse» ligger også benektelsen av at domstolene har frihet til å ikke begrunne ankenektelse. Å hevde at en kommune har vedtakskompetanse, er det samme å benekte at kommunen mangler vedtakskompetanse. Hohfelds tese om motsatser kan med dette betraktes som en enkel konstatering av at to logisk uforenlige regler ikke begge kan være gjeldende rett.

\footnotetext{
${ }^{31}$ Lov 27. november 1992 nr. 109 om gjennomføring i norsk rett av hoveddelen i avtale om Det europeiske $\emptyset$ konomiske samarbeidsområde (EØS) m.v.

32 Rt. 2000 s. 1811 (s. 1826 og 1831). Se også Høgberg (2019) s. 481.

${ }^{33}$ Eckhoff (1969) s. 85-86, 89 og 97.

${ }^{34}$ Eckhoff og Helgesen (2001) s. 334.

${ }^{35}$ Hohfelds innflytelse på Eckhoffs virke er nærmere omtalt i Wibye (2018) s. 497.
} 
Hohfelds begrepsapparat gir imidlertid ingen tilsvarende føringer for håndteringen av det andre tilfellet av rettighetskonflikt - pliktkollisjon. ${ }^{36}$ Eckhoffs syn på kollisjoner er beskrevet i større detalj i Rettssystemer, skrevet i samarbeid med Nils Kristian Sundby, hvor de to forfatterne hevdet følgende:

«l et normsystem hvor selvmotsigelser er eliminert, kan ikke samme handling være både påbudt og forbudt. En påbudt handling er altså ikke forbudt, og det vil si det samme som at den er tillatt. At en handling er påbudt impliserer mao. at den også er tillatt, og på tilsvarende måte impliserer forbud fritagelse ... Forbud og påbud er altså kontrære begreper. $1^{37}$

Som vi ser tok Eckhoff og Sundby utgangspunkt i det klareste (og også minst sannsynlige) eksempelet på pliktkollisjon, nemlig sammenstillingen av et påbud og et forbud. Deres påstand var at et påbud impliserte fraværet av forbud, og motsatt. De presenterte også en ytterligere måte å formulere spørsmålet om pliktkollisjon er et mulig tolkningsresultat. Ved å omformulere handleplikt til «påbud», avståelsesplikt til «forbud», fravær av forbud til «handlefrihet» («tillatelse») og fravær av påbud til «avståelsesfrihet» («fritak») ender man opp med en rekke ulike måter å stille samme spørsmål: ${ }^{38}$

1. Er pliktkollisjon et mulig tolkningsresultat?

2. Kan samme handling være underlagt både et gyldig påbud og et forbud?

3. Vil et påbud implisere en handlefrihet?

4. Vil et forbud implisere en avståelsesfrihet?

Eckhoff og Sundby besvarte de to første spørsmålene med et «nei» og de to siste med et «ja». Grunnen til at det er verdt å gjøre seg kjent med disse alternative måtene å stille samme spørsmål, er at man dermed blir i stand til å gjenkjenne den samme debatten i andre formater, som i Engs påstand om at «hvis handlingen er påbudt, så er den også tillatt; hvis den er forbudt, så er man også fritatt». ${ }^{39}$

Hva gjorde sammenstillingen av påbud og forbud umulig i Eckhoff og Sundbys øyne? Som vist i punkt 2 over, og som lagt til grunn av Eckhoff, kan ikke pliktkollisjon utelukkes gjennom et rent formallogisk resonnement. Dette er fordi et påbud ikke er den logiske negasjonen av et forbud, eller motsatt. Én mulig tolkning av Eckhoff og Sundbys avsnitt er som en rent definitorisk $\varnothing v e l s e$, hvorved ordene «påbud» og «forbud» forstås på en måte som utelukker kollisjon. Men en slik lesning av

\footnotetext{
${ }^{36}$ Se om dette Kramer mfl. (1998) s. 17-20.

${ }^{37}$ Eckhoff og Sundby (1991) s. 72-73.

${ }^{38}$ Ross (1953) s. 200, Arnholm (1964) s. 66, Hohfeld (1964) s. 39, Eckhoff og Sundby (1991) s. 80 og Torstein Eckhoff og Eivind Smith, Forvaltningsrett, 10. utg., Oslo 2014 s. 44-45 og 362.

${ }^{39}$ Eng (2007) s. 73.
} 
Rettssystemer har begrenset interesse for det underliggende spørsmålet om pliktkollisjoner er mulige tolkningsresultater. Selv hvis man slutter seg til den foreslåtte begrepsforståelsen, og dermed til at samme handling aldri kan beskrives som både «påbudt» og «forbudt», gjenstår det å ta stilling til om begrepene «plikt» og «frihet» må forstås på samme måte. ${ }^{40}$

En mer nærliggende lesning av Eckhoff og Sundby, er som en påstand om konsekvensen av deres innledende forutsetning om «et normsystem hvor selvmotsigelser er eliminert». ${ }^{41}$ Her synes Eckhoff og Sundby å ha postulert en slags overordnet norm - en metanorm - som sier at det er umulig for to kolliderende plikter å begge være gjeldende rett. At forfatterne postulerte en slik metanorm passer også med Eckhoffs utsagn i Rettskildelære om at man «aldri [kan] slå seg til ro med at det foreligger motstrid»; metanormens innhold er et påbud om å unngå motstrid. ${ }^{42}$

Hvordan skal man beskrive den postulerte metanormens innhold? En lignende norm er beskrevet i formallogikeren Moritz' kommentarverk til Hohfelds rettighetsanalyse. Moritz stipulerte at det finnes en alminnelig forutsetning hos jurister om at samme handling ikke kan være både påbudt og forbudt. Det er imidlertid viktig å merke seg Moritz' presisering av at denne normen må forutsettes. Normen kan ikke, ifølge Moritz, utledes av et formallogisk resonnement. ${ }^{43}$ I lys av denne presiseringen blir det noe skjevt når Eckhoff og Sundby både gjør bruk av det logiske implikasjonsbegrepet og beskriver utelukkelsen av pliktkollisjon som eliminasjon av «selvmotsigelser». «Selvmotsigende» er to utsagn først når de er logisk uforenlige. At et påbud og et forbud ikke begge kan oppfylles er en vanskelig situasjon for pliktsubjektet å stå i, men det er, slik Moritz slår fast, ingen logisk selvmotsigelse i å hevde at påbudet og forbudet finnes.

Metanormen som Eckhoff og Sundby forutsetter, er også eksplisitt beskrevet hos Sumner:

"If we assume that a rule system will not both require and prohibit the same act then if I am required to attend [a] meeting I am also permitted to do so. It follows that I have a liberty to do whatever I have a duty not to do. ${ }^{44}$

Sumners beskrivelse av metanormen samsvarer med Moritz' syn: Hvis man skal holde fast ved at samme handling ikke kan være påbudt og forbudt, må man først anta at det finnes en norm i

\footnotetext{
${ }^{40}$ Ifølge Cruft vil en slik forståelse av pliktbegrepet kreve en vesentlig omlegging av (det Hohfeldianske) pliktbegrepet som Eckhoff og Sundby ellers benytter, se Rowan Cruft, «Rights: Beyond Interest Theory and Will Theory?», Law and Philosophy 23, nr. 4 (2004) s. 394.

${ }^{41}$ Eckhoff og Sundby (1991) s. 72.

42 Eckhoff og Helgesen (2001) s. 343.

43 Moritz (1960) s. 47-48.

${ }^{44}$ Leonard W. Sumner, The Moral Foundation of Rights, Oxford 1987 s. 26.
} 
rettsordningen som utelukker pliktkollisjoner som tolkningsresultat. Fornektelsen av pliktkollisjon er ingen logisk nødvendighet. ${ }^{45}$ På grunn av en mer internasjonalt synlig profil har Sumners forutsatte metanorm også tiltrukket mer kritikk enn Eckhoff og Sundbys. ${ }^{46}$ Denne kritikken er direkte relevant for vurderingen av Eckhoff og Sundbys modell, og jeg vil komme tilbake til kritikken i punkt 4.

Eckhoff og Sundbys modell hviler på et ytterligere, taust premiss. Den postulerte metanormen tjener ikke bare til å avverge pliktkollisjoner som tolkningsresultat, den avslører pliktkollisjoner som tilsynelatende. Premisset kommer tydelig frem i Rettskildelære. Den tilsynelatende uforenligheten man observerer i retten kan, ifølge Eckhoff, ikke bestå mellom «de virkelig gjeldende regler, men reglene slik de i første omgang fortoner seg for oss». ${ }^{47}$ Påstanden er altså at illusjonen av kollisjon vil forsvinne så snart reglenes egentlige innhold presiseres, og at denne presiseringen skjer gjennom tolkning. Samme syn kan gjenfinnes hos Arnholm, som skyldte inntrykket av kollisjon på det faktum

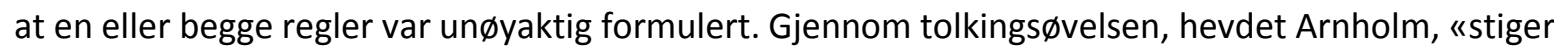
den virkelige norm og den virkelige plikt frem ${ }^{48}$

Det er uvisst om Eckhoff og Arnholm her innså at de gjengir en teori som går på tvers av retts- og moralfilosofi, og som normalt betegnes som «spesifikasjonsteori». I teoriens kjerne ligger en påstand om at konflikt mellom normer alltid vil oppløses så snart normene blir tilstrekkelig klarlagt. Inntrykket av kollisjon er altså en illusjon som skyldes manglende kunnskap om normenes innhold. Med en mer finmasket forståelse av normene vil man, ifølge spesifikasjonsteoretikere, alltid finne at plikt A stanser ved plikt $B$, som stanser ved plikt $C$ og så videre. Resultatet er, som Eckhoff skrev, at «det $i$ virkeligheten aldri er noen kollisjon mellom gjeldende rettsregler (innen ett og samme rettssystem)»». ${ }^{49}$ Det er ikke nødvendig med en full befatning med spesifikasjonsteori for å ta stilling til Eckhoffs syn på pliktkollisjon. I den grad drøftelsen i punkt 4 problematiserer hans rettssyn, vil imidlertid også spesifikasjonsteoriens styrker og svakheter bli berørt. ${ }^{50}$

\footnotetext{
${ }^{45}$ Sumner (1987) s. 23 og 33.

${ }^{46}$ Se f.eks. Kramer mfl. (1998) s. 17-18.

${ }^{47}$ Eckhoff og Helgesen (2001) s. 343. Jeg oppfatter Eckhoffs påstand om å være «nødt til å konstatere at det er en motstrid mellom [regler]» for anvendelse av kollisjonsprinsipper som en observasjon om «regler» $i$ betydning av mellomstasjoner for tankene, se Torstein Eckhoff, «Harmonisering av rettskildefaktorer og motstrid mellom regler», Jussens Venner (1980) s. 300. Denne forståelsen har også støtte i Eckhoff (1969) s. 81.
}

${ }^{48}$ Arnholm (1964) s. 128.

${ }^{49}$ Eckhoff (1969) s. 81.

50 Spesifikasjonsteori har primært blitt diskutert i sammenheng med moralske rettigheter. For omtale av spesifikasjonsteoriens anvendelse i en rettslig kontekst, se Christopher H. Wellman, "On Conflicts Between Rights», Law and Philosophy 14, nr. 3 (1995) s. 277 flg., José Juan Moreso, "Ways of Solving Conflicts of Constitutional Rights: Proportionalism and Specificationism», Ratio Juris 25, nr. 1 (2012) s. 36 fotnote 8 med videre henvisninger og Leto Cariolou, «Circumnavigating the Conflict Between the Right to Reputation and 
Det bør presiseres at Eckhoff og Arnholms tilslutning til spesifikasjonsteori på ingen måte følger av en eventuell tilslutning til rettsrealistisk metode. For rettsrealistene er utsagn om gjeldende rett å regne som en prediksjon, og hvor den sentrale kilden til prediksjonsdata er hva domstolene vil gjøre. ${ }^{51} \mathrm{Her}$ ville man kunne hevde at fordi pliktkollisjon aldri eksisterer i domsslutninger, så kan to kolliderende plikter heller aldri være gjeldende rett. Men spesifikasjonsteorien går forbi en påstand om at gjeldende rett er å finne i domsslutninger, og videre til en materiell påstand om hva disse domsslutningene nødvendigvis må inneholde. En slik materiell påstand kan ikke gjenfinnes i det rettsrealistiske prosjektet. Uavhengigheten illustreres kanskje tydeligst av at Ross, en av rettsrealistenes mest sentrale skikkelser, aksepterte pliktkollisjoner som mulige - hans syn vil bli videre omtalt i neste punkt.

For å oppsummere Eckhoffs modell: To logisk uforenlige rettsnormer kan ikke begge være gjeldende rett, fordi en og samme norm ikke kan både eksistere og ikke eksistere. Videre, to plikter kan ikke være gjeldende rett dersom oppfyllelsen av den ene innebærer overtredelse av den andre, fordi rettsordningen inneholder en metanorm som er til hinder for pliktkollisjon som tolkningsresultat. Gjennom tolkning blir det klart hvilken plikt som er den egentlig gjeldende, og kollisjonstilfellet blir dermed avslørt som tilsynelatende. Siden pliktkollisjonen nødvendigvis må avverges gjennom tolkning, kan kollisjonstilfeller aldri være reelle.

\subsection{Kelsens syn på pliktkollisjon}

Kelsens unders $\varnothing$ kelsesobjekt var rettens gyldighetskriterier. Han formulerte dermed artikkelens spørsmål på følgende måte: Kan to rettsnormer begge være gyldige dersom oppfyllelsen av den ene utelukker oppfyllelsen av den andre? Emnet er behandlet i åpningskapittelet av Reine Rechtslehre:

«It follows that within such a normative order [en sosial orden som pålegger sanksjoner] the same behavior may be - in this sense - commanded and forbidden at the same time, and that this situation may be described without logical contradiction. ... Under a legal order a situation may exist in which a certain human behavior and at the same time the opposite behavior is the condition of a sanction which ought to be executed. The two norms can be valid side by side. They can be described without logical contradiction, but they express two conflicting political tendencies, a teleological conflict. The situation is possible, but politically unsatisfactory.

the Right to Freedom of Expression», i When Human Rights Clash at the European Court of Human Rights, Stijn Smet og Eva Brems (red.), Oxford 2017 s. 172-173.

${ }^{51}$ Ross (1953) s. 47 og 84-85. 
Therefore legal orders usually contain rules according to which one of the two norms is invalid or may be invalidated. $»^{52}$

Det gjøres tre viktige grep i dette avsnittet. For det første la Kelsen til grunn at to rettsnormer som er i praktisk kollisjon, som ved et samtidig påbud og forbud, kan uttrykkes uten selvmotsigelse. Dette er i overensstemmelse med unders $\varnothing$ kelsen i punkt 2 over. For det andre hevdet Kelsen at slike pliktkollisjoner kan forekomme innenfor en og samme rettsorden. ${ }^{53}$ For det tredje, og fordi pliktkollisjoner er uheldige, mente Kelsen at rettssystemer flest vil inneholde egne regler for løsning av kollisjonstilfeller. Eckhoff og Sundbys postulerte metanorm er et eksempel på en slik norm. Forskjellen mellom deres modell og Kelsens, er at Kelsen ville betrakte metanormen som en betinget egenskap ved retten og ikke som en logisk selvfølge.

Kelsen skilte også tydelig mellom logisk uforenlighet og pliktkollisjon. Dette fremgår både av Reine Rechtslehre og av hans senere artikkel Derogation, hvor han i likhet med Eckhoff gjorde det klart at to logisk uforenlige utsagn aldri kan gi uttrykk for gyldige normer. ${ }^{54}$ Ved siden av Kelsens gjentakelse av at pliktkollisjoner er mulige, er Derogation interessant for dens beskrivelse av rettsvitenskapens rolle ved håndtering av kollisjon:

"That two mutually contradictory statements [logisk uforenlighet] should both be true, is impossible; that two mutually conflicting norms [pliktkollisjon] should both be valid, is possible. And this conflict cannot, like a logical contradiction, be resolved by way of knowledge, with the aid, say, of legal science. Legal science can only confirm the existence of this conflict, and must leave its resolution to the act of will of the legal authority, or to customary non-observance. $n^{55}$

Det kan ikke sies med sikkerhet om Kelsen og Eckhoff delte samme prosjekt. Nærmere bestemt er det uklart om Eckhoff realiserte den avstanden mellom rettsvitenskapsmannens og domstolenes perspektiv som så tydelig kom til uttrykk hos Kelsen. ${ }^{56}$ Likevel er det flere lærdommer å hente fra sammenligningen av disse to forfatternes syn på pliktkollisjon. Begge modeller er forenlige med en påstand om at pliktkollisjoner bør avverges. Kelsen beskrev som nevnt pliktkollisjoner som politisk

\footnotetext{
52 Hans Kelsen, Reine Rechtslehre, 2. utg., Wien 1960 s. 27. Oversettelsen er fra Hans Kelsen, Pure Theory of Law, Berkeley 1967 s. 25-26. Videre henvisninger vil gå til den opprinnelige utgivelsen.

${ }^{53} \mathrm{Jeg}$ setter her til side spørsmål knyttet til Kelsens tese om rettsenhet, og hans posisjon hva gjelder forenligheten mellom nasjonale og internasjonale rettsnormer, se videre Hart (1983) s. 309-342.

${ }^{54}$ Kelsen (1960) s. 212 og Kelsen (1973) s. 271.

${ }^{55}$ Kelsen (1973) s. 235.

${ }^{56}$ Det hersker bl.a. tvil om Eckhoff sluttet seg fullt ut til det rettsrealistiske prosjektet, se Hans Petter Graver, "Keiserens garderobe: Eckhoffs rettskildelære og utfordringer fremover», Tidskrift for Rettsvitenskap (2000), s. $439 \mathrm{flg}$.
} 
utilfredsstillende («politically unsatisfactory»). Fra at kollisjon er uønsket sluttet imidlertid ikke Kelsen at kollisjon er umulig. ${ }^{57}$ Hans diagnostiserende tilnærming står dermed i sterk kontrast med Eckhoff og Sundbys avvisning av kollisjonstilfeller som fiktive.

Det er også en kontrast mellom Kelsens modell og Eckhoffs tilslutning til spesifikasjonsteori. Der Eckhoff betraktet tolknings $\varnothing$ velsen som en avsløring av kollisjon som tilsynelatende, åpnet Kelsen for at kollisjoner er reelle inntil tidspunktet for rettsendring. I dette skiller pliktkollisjoner seg nok en gang fra logisk uforenlighet. Mens to kolliderende normer ifølge Kelsen kan være gyldige frem til tidspunktet for rettsendring, må ett av to logisk uforenlige utsagn om retten være usant fra første stund: «Derogation repeals the validity of one of the valid norms. But in case of logical contradiction between two assertions, one of the two assertions is untrue from the very beginning. ${ }^{58}$

Kelsens perspektiv inviterer også til en drøftelse av domstolenes rolle i kollisjonstilfeller. I den grad domstolene er rettsskapende, kan de også være kanalen for Kelsens forespeilede avverging av kollisjon gjennom rettsendring. Men norske domstoler agerer også som om gjeldende rettskildenormer setter føringer for deres tolkning. Hvis det skal være noen realitet $\mathrm{i}$ at domstolene er bundet av rettskildenormer, må det også være mulig å se for seg en situasjon hvor den harmoniserende tolkningen presser rettskildene for langt. Etter et slikt resonnement er det derfor tenkelig at tolkningsresultatet som har de beste grunner for seg, og som samsvarer best med gjeldende rettskildenormer, er å konstatere at det foreligger en pliktkollisjon. Neste punkt vil drøfte om mindretallsvotumet i Sårstell er et eksempel på nettopp en slik situasjon.

Kelsens modell blir mer interessant som sammenligningsgrunnlag gjennom støtten den har fått i nordisk teori. Det er først verdt å peke på likhetene mellom Kelsens syn og arbeidet til Torkel Opsahl. Opsahl skilte, som både Kelsen og Eckhoff, mellom pliktkollisjon og logisk uforenlighet. Han holdt det som «absurd» at to logisk uforenlige regler begge skulle være gjeldende rett. ${ }^{59}$ I likhet med Kelsen tok han også avstand fra spesifikasjonsteoretikeres syn på rettsanvendelse. Mens Opsahl sluttet seg til Eckhoffs antagelse om at kollisjoner normalt vil bli eliminert gjennom tolkning, holdt han også fast ved at tolkningsøvelsen - å «forlike regler» - var med på å endre retten. ${ }^{60}$ Et slikt syn kan vanskelig forlikes med spesifikasjonsteoriens påstand om at enhver pliktkollisjon er tilsynelatende fra første stund.

\footnotetext{
57 Kelsen (1960) s. 27 og 209-210.

${ }^{58}$ Kelsen (1973) s. 271. Se også Kelsen (1973) s. 235.

59 Opsahl (1965) s. 296.

${ }^{60}$ Opsahl (1965) s. 291. For en prinsipielt begrunnet versjon av samme syn, se Cass Sunstein, Legal Reasoning and Political Conflict, Oxford 1998 s. 128.
} 
Mest interessante er forbindelseslinjene mellom Kelsen og Alf Ross. De to forfatterne formulerte den sentrale spørsmålsstillingen på samme måte: Kan to kolliderende rettsnormer begge være gyldige? ${ }^{61}$ Ross' svar levner heller ingen tvil om at det går et skille mellom pliktkollisjon og logisk uforenlighet: Mens han betraktet pliktkollisjon - en lov som både påbyr og en som forbyr - som urimelig, regnet han logisk uforenlighet - en lov som både påbyr og ikke påbyr - som rent sludder. ${ }^{62} \mathrm{Av}$ Ross' beskrivelse av kollisjonstilfellet følger også at han ikke regnet det som en praktisk umulighet. Som illustrasjon beskrev Ross et land der to religiøse sekter kniver om overtaket. Den ene sekten kommer til makten, og innfører en lov som sier at det er forbudt å bruke hatt når man går forbi religiøse helligdommer. Deretter kommer den andre sekten til makten, og innfører en lov som sier at det er påbudt å bruke hatt når man går forbi helligdommer. De unnlater imidlertid å oppheve det opprinnelige forbudet. Samme handling, det vil si å bruke hatt, er nå både forbudt og påbudt. ${ }^{63}$ Til dette eksempelet på pliktkollisjon kan man innvende at det tidligere forbudet blir opphevet idet påbudet innføres. Men det er ingen logisk nødvendighet $\mathrm{i}$ at rettsordningen inneholder en norm som lex posterior, hvorved en ny rettsregel går foran eldre rettsregler. Betydningen av slike betingede normer for kollisjonstilfeller drøftes videre i neste punkt.

Til slutt er det verdt å nevne hvordan Kelsens modell har forplantet seg videre gjennom arbeidene til den engelske rettsfilosofen H.L.A. Hart. Hart beskrev kollisjonstilfellet slik: ${ }^{64}$

«The crudest case of such a conflict are rules which respectively require and forbid the same action on the part of the same person at the same time or times ... Joint obedience to these rules would be logically impossible, but their coexistence as valid rules would be logically possible.... [T]hough it would certainly be deplorable on every practical score if laws of a single legal system conflicted and the system provided no way of resolving such conflicts, it is still far from obvious that even this is a logical impossibility. ... [T]hough we might think a person who gave inconsistent orders at short intervals to the same person mad or splitminded or lacking a coherent will and perhaps in need of clinical attention, such situations do not seem logically impossible. ${ }^{65}$

I dette avsnittet understrekes at to kolliderende plikter kan beskrives uten selvmotsigelse selv om det ikke er mulig å oppfylle dem samtidig. ${ }^{66}$ Denne sondringen er som nevnt $n \varnothing$ dvendig om man skal

\footnotetext{
${ }^{61}$ Ross (1968) s. 153.

62 Ross (1968) s. 174.

${ }^{63}$ Ross (1968) s. 172-174.

${ }^{64}$ Hart (1983) s. 18 og 286.

${ }^{65}$ Hart (1983) s. 325-326.

${ }^{66}$ Det samme skillet beskrev han ved konflikt mellom en moralsk norm og en rettsnorm: «'There are good legal reasons for doing $A$ and good moral reasons for not doing $A^{\prime}$. This expresses a conflict because it is logically
} 
forsvare Eckhoffs beskrivelse av pliktkollisjon som et tilfelle av «logisk motstrid». Beskrivelsen kan brukes om oppfyllelseshandlinger, men ikke om de underliggende normene. Det følger også av dette avsnittet at Hart ikke så noen logisk nødvendighet $i$ at et rettssystem skal ha mekanismer for å avverge kollisjoner (i kontrast til Eckhoff og Sundbys postulerte metanorm). Hart påpekte imidlertid at en lovgiver som skaper tilsiktede eller utilsiktede kollisjoner, vil tape legitimitet. Dette hensynet vil bli drøftet i punkt 4.

For å oppsummere Kelsens modell, var den fundert på et skille mellom logisk uforenlighet og pliktkollisjon. Mens to logisk uforenlige utsagn ikke begge kan beskrive gyldige rettsnormer, anså Kelsen det som mulig for to kolliderende plikter å begge være gyldige rettsnormer. En rettsordning inneholder ofte normer for avvergelse av kollisjoner. Fra disse normene, og fra at kollisjoner er uønskede, kan man imidlertid ikke slutte at kollisjoner er fiktive. Om det ikke er rom for å fornekte kollisjoner på teoretisk grunnlag, kan det heller ikke være rettsvitenskapens oppgave å fastholde at alle kollisjoner avsløres som tilsynelatende gjennom en harmoniserende tolkning. Det må heller være rettsvitenskapens oppgave å synliggjøre dem, for deretter å overlate kollisjonstilfellets eventuelle løsning til en lovgivende myndighet.

\section{Drøftelse}

\subsection{Metanormer for håndtering av pliktkollisjon}

Tverrsnittet av rettsteori viser to hovedleirer: De som mener at harmoniserende tolkning avslører enhver kollisjon som tilsynelatende, representert av blant annet Eckhoff, Sundby og Arnholm, og de som holder fast ved at pliktkollisjon er et mulig tolkningsresultat, representert av blant annet Kelsen, Hart og Ross. Spørsmålet videre er hvilket av disse svarene som er mest konsekvent og i samsvar med juridisk virkelighet. Jeg vil drøfte dette spørsmålet både prinsipielt og som spørsmål om hvordan vi best kan forstå rettsoppfatningen uttrykt av mindretallet i Sårstell.

Hvis man vil gjøre som skeptikerne og bruke en metanorm til å utelukke pliktkollisjoner som tolkningsresultat, så må man kunne beskrive metanormens innhold. Til denne oppgaven hører å spesifisere hvilket tolkningsresultat denne normen gir anvisning på. Presiseringen er nødvendig fordi kollisjon mellom plikter kan avverges på flere alternative måter. Om vi holder oss til Ross' eksempel på et kombinert påbud og forbud for bruk av hatt, er det fire mulige tolkningsutfall:

(a) Et påbud om å bruke hatt uten forbud (plikt og frihet til å handle).

(b) Et forbud mot å bruke hatt uten påbud (plikt og frihet til å avstå fra å handle).

(c) Verken forbud mot å bruke hatt eller påbud om å bruke hatt (valgfrihet).

impossible for one person at the same time to do both A and not A. But it does not, as far as I can see, assert anything contradictory or logically impossible.» Hart (1983) s. 308. Sml. Hill (1987) s. 229. 
(d) Et kombinert påbud og forbud (pliktkollisjon).

Normen av den type som Eckhoff og Sundby postulerte, utelukker resultat (d). Utelukkelsen gir imidlertid liten veiledning for det påfølgende valget mellom utfall (a), (b) og (c). Hvordan skal man så hevde at dette valget er diktert av rettslige normer? Et mulig svar er formulert hos Kelsen, som for $\varnothing v r i g$ også godtok (d) som et mulig svar. I en rettsordning som har regler for avvergelse av kollisjoner, hevdet Kelsen at tolkningsresultatet, altså valget mellom (a), (b) eller (c), i praksis avgjøres ved bruk av typetilfeller, og at disse typetilfellene kommer til uttrykk som rettskildeprinsipper. ${ }^{67}$ Ifølge Kelsen blir altså metanormens rolle fylt av prioritetsnormene som i rettskildelæren kalles kollisjonsprinsipper. ${ }^{68}$ Et lignende syn på lex superior-prinsippet ble lagt frem av Opsahl. ${ }^{69}$ Fire sider ved dette svaret er verdt å fremheve:

En, svaret innebærer at rettskildeprinsippene for regulering av kollisjon får status som selvstendige normer. Sett at eieren av et kraftverk først får et pålegg etter energiloven § 6-2 (1) om å igangsette produksjon av kraft og deretter et pålegg om å avstå fra produksjon. Det er da ikke det nye forbudet selv som kansellerer gyldigheten av det tidligere påbudet. Prioriteringen skjer gjennom en tredje, ekstern norm, i dette tilfellet en norm ved navn lex posterior. Denne normen angir at ved motstrid mellom to regler av samme rang, skal den eldre regelen vike for den yngre.

To, det er fremdeles ingen formallogisk nødvendighet i svaret om at en trinnlavere norm, en eldre norm eller en mer generell norm må vike. ${ }^{70}$ At det finnes slike kollisjonsprinsipper er en betinget egenskap ved vår rettsordning.

Tre, det er heller ikke gitt at svaret som kollisjonsprinsippene gir, behandles som bindende. Rettspraksis inneholder flere eksempler som er vanskelige å forlike med en streng anvendelse av kollisjonsprinsipper. ${ }^{71}$ Dette er også noe vi burde forvente å se. Å hevde, for eksempel, at en trinnlavere norm alltid må vike, er også å sette til side enhver materiell vurdering av de to normenes innhold. Slik tilsidesettelse harmonerer dårlig med den juridiske metodens ambisjon om å finne frem til resultater som alle forhold tatt i betraktning har de beste grunner for seg. ${ }^{72}$

\footnotetext{
${ }^{67}$ Kelsen (1973) s. 271-272.

68 Helgesen (1979) s. 8-9, Høgberg og Høgberg (2019) s. 253 og Høgberg (2019) s. 497-501.

${ }^{69}$ Opsahl (1965) s. 291-299.

${ }^{70} \mathrm{H} \varnothing$ gberg og Høgberg (2019) s. 251.

${ }^{71}$ Eckhoff (1969) s. 79.

72 Per Augdahl, Rettskilder, 3. utg., Oslo 1973 s. 27-28 og Høgberg og Høgberg (2019) s. 252-253.
} 
Fire, kollisjonsprinsippene har et avgrenset virkeområde, i den forstand at det finnes

tolkningsspørsmål som de ikke gir svar på. ${ }^{73}$ Dermed oppstår det sentrale spørsmålet om muligheten for kollisjonstilfeller på nytt, som spørsmål om hvordan man skal behandle resttilfellene. Da vil det være sirkulært å svare at om prioritetsnormene ikke løser kollisjonstilfellet, så utelukkes kollisjon ved at man velger tolkningsresultatet som etter en helhetsvurdering har de beste grunner for seg. For hva er til hinder for at tolkningsalternativet som har de beste grunner for seg, nettopp er å konstatere at det foreligger en pliktkollisjon? Å svare at kollisjon aldri kan være tolkningsresultatet i tilfeller som faller utenfor kollisjonsprinsippenes rekkevidde, er bare en annen måte å hevde at pliktkollisjoner er umulige tolkningsresultater; det gjenstår fremdeles å forklare hvorfor. Dette forklaringsbehovet er særlig godt illustrert gjennom mindretallets votum i Sårstell.

\subsection{Forholdet mellom benektelsen av pliktkollisjoner og mindretallets votum i Sårstell}

De rettslige sidene ved hjemmelsspørsmålet i Sårstell har allerede blitt kommentert en rekke ganger, og trenger ingen gjentakelse her. Det avgjørende er ikke om flertallet eller mindretallets rettsforståelse var å foretrekke, men hvordan rettsvitenskapen skal forholde seg til mindretallets konklusjon om at hverken den forvaltningsrettslige vilkårslæren eller sykehjemsforskriften oppfylte kravet om hjemmel for bruk av tvang. ${ }^{74} \AA$ konstatere både at sykehjemmet hadde en behandlingsplikt og at sykehjemmet manglet hjemmelen som trengtes for å oppfylle den behandlingsplikten, synes å innebære at sykehjemmet sto overfor et pliktbrudd som ikke kunne unngås. De kunne enten bryte tvangsforbudet og oppfylle behandlingsplikten, eller respektere tvangsforbudet og unnlate å oppfylle behandlingsplikten. Noe - en av to interesser beskyttet av en rettsnorm - ville altså måtte ofres. ${ }^{75}$ Noe av det som gjør Sårstell så interessant, er at mindretallets dommer Webster later til å ha innsett den vanskelige stillingen som tolkningen skapte for sykehjemmet:

«Når jeg også kommer til at det ikke er grunnlag for å benytte tvang, er jeg fullt på det rene med at dette setter institusjonen i en vanskelig stilling. Sykehjemmet har åpenbart behov for å kunne

\footnotetext{
${ }^{73}$ Aarbakke (1966) s. 503.

${ }^{74}$ For videre omtale, se Aslak Syse, «'Huleboerdommen' - feil navn og uklart innhold?», Lov og Rett (2011), s. 628-637, Njål W. Andersen og Karl O. Wallevik, «'Huleboerdommen' - riktig diagnose, feil medisin?», Lov og Rett (2011), s. 283-297, Alice Kjellevold og Henriette S. Aasen, «Huleboer-dommen og bruk av tvang i sykehjem», Tidsskrift for erstatningsrett, forsikringsrett og trygderett (2011), s. 50-68; Erik Monsen, "En kommentar til Sårstelldommen», i Undring og erkjennelse. Festskrift til Jan Fridthjof Bernt 70 år, Karl Harald Søvig, mfl. (red.), 2013 s. 419-429, Bjørn H. Østenstad, «Sårstelldommen - prejudikat for kva?», Lov og Rett (2014) s. 484-501, Jan F. Bernt, "Krav om forholdsmessighet ved kontroll av offentlig myndighetsut $\varnothing v i n g », ~ i$ Forholdsmessighetsvurderinger i forvaltningsretten, Karl H. Søvig (red.), Bergen 2015 s. 27-33 og Wibye (2018) s. 519-527.

${ }^{75}$ Se L. Zucca i Stijn Smet og Eva Brems, When Human Rights Clash at the European Court of Human Rights, Oxford 2017 s. 104.
} 
tvinge A til alminnelig hygiene, særlig ut fra hensynet til de ansatte. As beveggrunner for å nekte å motta helsehjelp kan ikke - i alle fall ikke fullt ut - oppveie de ulempene de ansatte påføres. Jeg mener imidlertid at det å benytte tvang mot A - og andre personer som er i institusjon - må bygge på et tilstrekkelig klart hjemmelsgrunnlag. I dette tilfelle foreligger ikke tilstrekkelig hjemmel, og det er en lovgiveroppgave å gi hjemmel - og fastsette de vilkårene og rettsikkerhetsgarantiene som skal gjelde for slik tvangsbruk.» (avsnitt 54-55)

Pasienten skapte betydelige luktplager, og det var ingen tvil om at situasjonen for sykehjemmets ansatte var nærmest uutholdelig. I tillegg til interessen i et levelig arbeidsmiljø kom behovet for å oppfylle behandlingsplikten. Slik flertallet la til grunn, ville en utskrivning av pasienten uten tilbud om tilsvarende pleie fra et annet sted være «uforenlig» med kommunens plikter til å tilby helsetjenester etter kommunehelsetjenesteloven § 2-1 (avsnitt 35).

Artikkelen startet i et spørsmål om pliktkollisjoner er mulige tolkningsresultater, og det synes her som om mindretallet gjorde nettopp det Eckhoff hevdet man aldri kunne gjøre, nemlig å «slå seg til ro med at det foreligger motstrid» mellom regler. ${ }^{76}$ For å forlike Eckhoffs påstand med resultatet i Sårstell, er man nødt til å hevde enten at mindretallets resultat ikke utgjorde en reell pliktkollisjon (hvilket samsvarer dårlig med den faktiske og rettslige situasjonen), eller at mindretallet formentlig var avskåret fra å konkludere som de gjorde. Jeg skriver «formentlig» fordi det er uklart hvordan man skal forholde seg til en påstand om at domstolen var avskåret fra å treffe en bestemt avgjørelse. Igjen kan man forsøke å forestille seg hva som ville skjedd hvis flertallet og mindretallet i Sårstell var snudd, og konklusjonen ble at sykehjemmet manglet tvangshjemmel. Fra et rent praktisk ståsted ville resultatet bety at sykehjemmets tidligere bruk av tvang var i strid med en plikt, med en påfølgende mulighet for at kommunen kom i økonomisk ansvar. Det synes ikke å være noe grunnleggende i veien med et slikt utfall. Skulle man da likevel hevde at domstolens resultat lå utenfor det rettslig tillatte? Hvilket syn på rettsbegrepet ville en slik påstand være uttrykk for? Ville den bety at rettsavgjørelsen ikke var uttrykk for gjeldende rett? Gitt at dette fremdeles er et tankeeksperiment, er det ikke rom for å forfølge disse grunnleggende spørsmålene om forholdet mellom rettspraksis og rettsbegrepet her.

Ulike prinsipielle spørsmål satt til side, gjenstår spørsmålet om hvordan rettsteoriens syn på pliktkollisjoner skal forlikes med mindretallets votum. Her er tilsynelatende et eksempel på at to høyesterettsdommere, etter en nøye gjennomgang av det tilgjengelige rettskildematerialet, konkluderer at tolkningsresultatet som har de beste grunner for seg innebærer en pliktkollisjon. Det er på ingen måte klart hvorfor dette resultatet skal være utelukket av rettskildelærens kollisjonsprinsipper, eller hvorfor en kategorisk utelukkelse av dette resultatet skal lede til gode

\footnotetext{
${ }^{76}$ Eckhoff og Helgesen (2001) s. 343.
} 
tolkningsresultater. Kanskje hadde det vært bedre i Sårstell å akseptere at regelverket la opp til en uunngåelig pliktkollisjon, og at dette var et problem ved regelverket som bare kunne løses gjennom en regelendring. Alternativet var å gjøre som flertallet, og identifisere et hjemmelsgrunnlag for bruken av tvang. Dette er et resultat som en rekke kommentatorer har betegnet som frirettslig, ukonvensjonelt og mangelfullt begrunnet. ${ }^{77}$

Etter denne gjennomgangen er det altså flere åpne spørsmål knyttet til forslaget om at pliktkollisjoner er utelukket av rettskildelærens kollisjonsprinsipper. Disse prinsippene kan håndtere mange kollisjonstilfeller, men ikke alle. Det er ingen logisk nødvendighet i deres anvendelse. Og deres anvendelse leder ikke nødvendigvis til optimale tolkningsresultater. Med disse spørsmålene gjenstår det også fremdeles en betydelig usikkerhet om hva som er det nøyaktige innholdet i den postulerte normen for utelukkelse av pliktkollisjon. Å basere rettsvitenskapelig analyse på forutsetningen om at en slik metanorm finnes, skaper et etterprøvbarhetsproblem (Hvordan beskrive metanormens innhold?), et synliggjøringsproblem (Er vi tjent med å skjule valget av tolkningsresultat bak en metanorm hvis innhold er uklart?) og et korrespondanseproblem (Hva hender når metanormen ikke er i stand til å forklare rettslige utfall?). De to siste problemene drøftes videre i neste punkt.

\subsection{Pliktkollisjon som tolkningsresultat}

Som nevnt ser det intuitive argumentet mot pliktkollisjoner overbevisende ut på overflaten. Et pliktutsagn, som for eksempel «Du har plikt til å behandle denne pasienten» eller «Du har plikt til å produsere kraft», tolkes normalt som at man har frihet til å oppfylle plikten. Dette utgangspunktet er også godt eksemplifisert i saker som aktualiserer en alminnelig rettsstridsreservasjon. Et eksempel er Rt. 2013 s. 1442, hvor legen sto A overfor et dilemma. Han var i ferd med å overlevere en pose med narkotika til politiet, men var også bevisst på at han hadde en plikt til å ivareta anonymiteten til posens eier. A valgte å gni posen mellom sine egne hender $f \varnothing r$ han ga den videre. Han ble deretter tiltalt for bevisforspillelse etter straffeloven $\S 132$, men hevdet at hans handling var rettmessig som følge av hans plikt til å ivareta taushetsplikten etter helsepersonelloven $\S 21 .{ }^{78} \mathrm{Her}$ forelå en potensiell kollisjon mellom taushetsplikten og plikten til å avstå fra bevisforspillelse, men kollisjonen ble avverget ved å innskrenke en av pliktene. Slik retten la til grunn, kunne ikke tiltalte domfelles om hans handling var påkrevd for å ivareta taushetsplikten. Retten fant videre at A handlet innenfor taushetsplikten når han valgte å gni posen mellom hendene før overlevering.

Intuisjon og praksis gir med dette gode holdepunkter for å hevde at man må ha frihet til å gjøre det man har plikt til å gjøre. Uten slik frihet ville det være umulig å handle rettmessig, og slik Arnholm

\footnotetext{
77 Kjellevold og Aasen (2011) s. 67, Syse (2011) s. 634, Bernt (2015) s. 45 og Wibye (2018) s. 522-525.

${ }^{78}$ Lov 2. juli 1999 nr. 64 om helsepersonell m.v.
} 
spurte, retten kan vel ikke kreve det umulige ${ }^{79}$ I dette spørsmålet ligger det imidlertid en terminologisk uklarhet, ettersom det er uklart om den tilsiktede umuligheten er av normativ eller logisk art. Arnholms spørsmål illustrerer også hvor nærliggende det er med en feilslutning fra et normativt «bør» til et analytisk «er». ${ }^{80}$ Det er på det rene at pliktkollisjoner er noe rettsordningen $b \varnothing r$ fors $\varnothing$ ke å unngå. Denne påstanden tilsluttes av alle forfatterne som har blitt omtalt i denne artikkelen. Det er også plausibelt at påstanden fungerer som rettesnor ved utforming og tolkning av retten, slik den gjorde hos flertallet i Sårstell. Av disse utgangspunktene følger det imidlertid fremdeles ikke at pliktkollisjoner er utenkelige. Hvis pliktkollisjoner skal være utelukket, er det nødvendig å finne et videre grunnlag enn en henvisning til Arnholms retoriske spørsmål.

Hva med å forstå umuligheten av pliktkollisjoner som et resultat av en kompetansebegrensning hos lovgiver? Dette synet går ut på at det ligger utenfor lovgivers kompetanse å skape pliktkollisjoner, og at en av to kolliderende pliktene derfor ikke kan være gjeldende rett. Et første problem med denne tilnærmingen er at den ikke gir veiledning om hvilken av pliktene som er gjeldende rett og hvilken som skal vike. Som ved Eckhoff og Sundbys metanorm gjenstår det altså å forklare hvordan lovgivers eventuelle kompetansebegrensning virker inn på tolkning.

Et videre problem med å hevde at det ligger utenfor lovgivers kompetanse å skape pliktkollisjoner, ligger $\mathrm{i}$ selve forutsetningen om at det finnes grenser for rettens normeringsevne. Dette er en utsatt posisjon å innta. Det konkurrerende synet er at rettssystemet, som en normativ orden, karakteriseres av en utt $\varnothing$ mmende normeringsevne. ${ }^{81}$

Et tredje problem for påstanden om at det ligger utenfor lovgivers kompetanse å skape pliktkollisjoner, er at det er mulig å forestille seg en rekke scenarier hvor lovgiver gjør nettopp dette. Det mest sannsynlige er ikke at en lovgiver med onde hensikter skaper pliktkollisjoner med vilje, men at det oppstår utilsiktede kollisjoner som følge av koordineringsfeil. ${ }^{82}$ Idet reglene for behandling og bruk av tvang i sykehjem ble utformet, kan det hende man ikke vurderte muligheten for at samtykkekompetente pasienter ville velge å motsette seg behandling. Mange lignende situasjoner kan tenkes. En moderne rettsordning har svært mange bevegelige deler, og det har formodningen mot seg at lovgiver er i stand til å overskue, og forebygge, ethvert tenkelig kollisjonstilfelle.

Eckhoff og Arnholms spesifikasjonsteori håndterer kolliderende plikter ved å nekte for at begge kan være gjeldende rett og å hevde at tolkningen vil avsløre kollisjonen som tilsynelatende. Denne

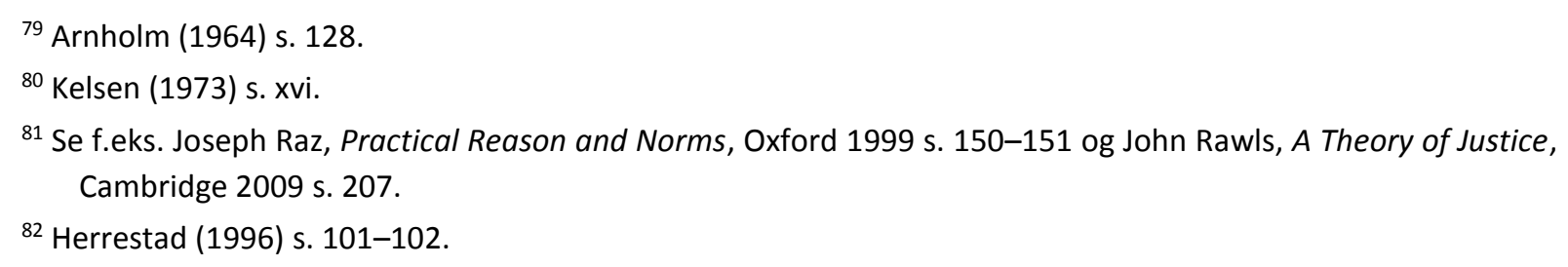


Øøsningen underkommuniserer imidlertid den reelle utfordringen som pliktsubjekter kan bli stilt overfor når lovgiver først har trådt feil. Når regelverket tilsynelatende gir anvisning på to plikter som det ikke er mulig å oppfylle, så er pliktsubjektet nødt til å foreta et valg mellom to uheldige (og usikre) alternativer. Dette synes også å ha vært realiteten i Sårstell. Kommunen var kjent med muligheten for at det ikke var hjemmel for å bruke tvang. Sykehjemmets ansatte valgte likevel å ty til tvang. På tidspunktet for deres avgjørelse hjalp det trolig lite at den etterfølgende domstolsbehandlingen ville identifisere en tvangshjemmel ved hjelp av vilkårslæren. ${ }^{83}$

Kelsens alternativ til påstanden om at retten ikke kan kreve det umulige, var å holde fast ved at retten ikke $b \varnothing r$ kreve det umulige, men at pliktkollisjon dessverre er en reell mulighet. Med en slik aksept av muligheten for pliktkollisjoner, ledes vi til et siste spørsmål: Har vår rettsordning de nødvendige verktøyene for å håndtere et uunngåelig pliktbrudd? Det har den utvilsomt. Om flertallet i Sårstell hadde konkludert med at hjemmelskravet ikke var oppfylt, ville sykehjemmets tidligere handlinger bli regnet som et pliktbrudd, som igjen ville kunne utløse sanksjons- og erstatningsmekanismer. Det er også mulig at saken ville foranledige lovendringen som Kelsen mente var nødvendig for å nøytralisere reelle tilfeller av kollisjon.

\section{Oppsummering}

Pliktkollisjon foreligger når det er umulig å oppfylle en plikt uten å bryte en annen. Slike kollisjonstilfeller er vesensforskjellige fra tilfeller av logisk uforenlighet mellom to gjensidig utelukkende utsagn om retten.

To modeller for håndtering av pliktkollisjoner har blitt beskrevet. Eckhoff og Sundbys modell stipulerer en metanorm for utelukkelse av pliktkollisjoner som tolkningsresultat. Deres er en form for spesifikasjonsteori, med en tilhørende påstand om at tolkning avslører ethvert tilfelle av pliktkollisjon som tilsynelatende. Kelsens modell, derimot, åpner for at to kolliderende plikter begge kan være gjeldende rett. Kelsens tilnærming er forenlig med det normative ønsket om å unngå kollisjoner, men holder fast ved at kollisjoner ikke kan utelukkes på teoretisk grunnlag. Kollisjoner avverges gjennom endring av retten og eksisterer frem til endringstidspunktet.

Sammenholdes disse to modellene med mindretallets votum i Sårstell, synes det å innebære en større fiksjon å holde fast ved at pliktkollisjoner er umulige tolkningsresultater, enn det er å anerkjenne mindretallets resultat som et (sjeldent) eksempel på en reell kollisjon mellom to plikter.

\footnotetext{
${ }^{83}$ Kronologien i disse sakene reiser også spørsmål om Eckhoff og Arnholms modell innebærer en form for rettslig determinisme - en påstand om at det alltid finnes ett, og bare ett, riktig svar på ethvert tolkningsspørsmål over en innrømmelse av at rettens institusjoner skaper ny rett gjennom deres tolkning og rettsanvendelse. Dette er imidlertid et spørsmål som det vil føre for langt å drøfte her. Se videre Joel Feinberg, "Voluntary Euthanasia and the Inalienable Right to Life», Philosophy \& Public Affairs (1978), s. 101.
} 
Hvis man vil holde fast ved at pliktkollisjoner er umulige tolkningsresultater, må det gis en mer fyldig begrunnelse enn norsk teori så langt har tilbudt. Den stipulerte normen om at kollisjoner må avverges, gir ufullstendig veiledning om hvilket tolkningsresultat som skal velges for å unngå kollisjonen. Det er også uklart hva som leder til at lovgiver er avskåret fra å skape pliktkollisjoner. Fra et normativt «bør» - en forestilling om at retten ikke bør kreve det umulige - kan man ikke gå direkte til et analytisk «er» - en påstand om at retten ikke kan kreve det umulige. Avvisningen av pliktkollisjoner bidrar også til å underkommunisere den reelle utfordringen pliktsubjekter står overfor når regelverket tilsynelatende gir anvisning på to kolliderende plikter.

Påstanden om at domstolene ikke kan slå seg til ro med kollisjon, kan utfordres gjennom et enkeltstående eksempel på pliktkollisjon som tolkningsresultat. Slik jeg ser det, kan mindretallets votum i Sårstell tjene som dette eksempelet. Eckhoff og Arnholms retroaktive identifikasjon av den egentlige rettsnormen er en teoretisk elegant løsning på kollisjonstilfellet. Men lik flertallets votum i Sårstell, kan den også ligne en etterfølgende rasjonalisering av et uheldig eller lite gjennomtenkt regelverk. Dette regelverket er det lovgiveren, og ikke rettsteoretikere, som står til ansvar for. 